\title{
Social orphanhood - towards learning and understanding to bring help
}

\section{KEYWORDS}

social orphanhood, parental attitudes, parental errors, consequences of social orphanhood

\begin{abstract}
Monika Kiszka, Social orphanhood - towards learning and understanding to bring help. Culture - Society Education no. 1(19) 2021, Poznań 2021, pp. 191-202, Adam Mickiewicz University Press. ISSN 2300-0422. DOI 10.14746/kse.2021.19.13

The goal of the article is to describes the impact of parental behaviour on children's lives. The main body discusses the neglect of parental duties and the misguided attitude towards raising children exhibited by some parents. Additionally, the article describes the phenomenon of orphanhood and its connection with the problems that some parents are unable to cope with. The second part focuses on the most harmful consequences of certain negative behaviours exhibited by some parents. The final part of the article is a list of personality disorders and the other problems that children suffering from social orphanhood may experience.
\end{abstract}

\section{Social orphanhood: understanding of the concept}

In attempting to understand orphanhood, the discussion should focus mostly on consequences rather than the main characteristic features that impact on the quality of children's future lives as adults. However, before I describe orphanhood in detail, I will outline the motivation for writing this article. In the constantly changing world, the problem of orphanhood is sidelined in public discussion. The

\footnotetext{
* ORCID https://orcid.org/0000-0003-0489-3902.
} 
article below should draw attention to the current situation of children affected by orphanhood. Afterthoughts should revolve around the main questions that are connected with the possible chances of children experiencing improved care. The most important thing is to develop practical tools that can minimise the negative consequences of orphanhood. The basis for theoretical implications should be a social discussion about orphanhood.

Social orphanhood is discussed in the pedagogical and psychological sciences. Social orphanhood, as presented in the literature, has a wide interpretative range. The basic meaning of this concept indicates that it is a situation in the child's life marked by a lack of parenting and care. Such inactivity on the part of caregivers leads to parental tasks being taken over by a care institution. A feature that characterizes social orphanhood is that children are deprived of their natural environment, of having their own family (Olearczyk, 2007: 102). The literature defines the concept of social orphanhood in relation to children living in orphanages. It is a definition in the strict sense. In its broad sense, it refers to determining the situation of children remaining in their own families when the caregivers fail to fulfil their parental responsibilities. When providing the basic definition of the concept, it should be assumed that these are all bio-psychosocial phenomena that are based on the type of relationship and bond between parents and their child. In the Polish literature on the topic, the concept of orphanhood was first presented in the statistics of the Central Statistical Office of Poland in 1967 (Olearczyk, 2007: 16).

When producing a detailed description of the concept of social orphanhood, one should refer to the definition produced by Stanisław Kozak, who indicates the lack of parental care appearing in the relationship between the child and parents. The main factors causing disturbances in family life include the lack of concern for the child, various types of addictions and committing serious parenting errors. Kozak's definition emphasizes the fact that both parents live with the child, yet they do not exercise adequate parental care (Kozak, 1986: 13).

Stanisław Kazak's definition of social orphanhood is related to the social work approach adopted and presented by Barbara Czeredrecka. This term is used to describe the situation in a child's family. One of the first elements mentioned here should be the lack of proper care leading to the necessity of placing the child in total care facilities to take over parental responsibilities. The author covers the reasons for the failure to exercise parental care, which might be caused by addictions or violence. Not fulfilling parental tasks can properly be associated with committing parenting errors, but also with manifesting attitudes of rigour, coolness and indifference towards the child (Czeredrecka, 1988: 45-47). 
With regard to the phenomenon of social orphanhood, reference should be made to its basic typology. This phenomenon can be divided into explicit and hidden social orphanhood. The former is much more unambiguous. Most of the time it manifests itself as the parents waiving their rights to the child and transferring the child to institutional guardianship. The other manifestation of the phenomenon is the termination of parental rights due to the demoralization of parents or other factors contributing to the dysfunctionality of the family. Hidden social orphanhood is described as a child's situation that is not noticeable in the form of external symptoms. Maria Ziemska describes this situation as mental and emotional neglect of the child. Parents clearly reject the child and their duties towards the child (Ziemska, 1973: 44). It can be also manifested as an attitude of excessive rigor towards the child.

One should also refer to the views of Alicja Szymborska, who, when defining social orphanhood, refers to the severity of the child's neglect. All the contacts listed below refer to the situation when the child has already been placed in an orphanage or other form of institutional care. The first degree is characterized by the highest degree of child abandonment and social orphanhood. It can be described as a complete break in the relationship between child and parents. For the next two degrees, the relationship parents have with their child is characterized by a low frequency of meetings with the child, yet not a complete termination of their mutual bond. The contact parents have with the child can be described as unsystematic and unintentional. It can manifest itself in the following manner: the parents are interested in the child and the progress they make in learning, although they do not strive for systematic meetings with the child and spending holidays together. The third degree of contact can be described as meeting the child unsystematically and disappearing for a certain period of time, only to resume contact at a specified time following the break period (Sołtysiak, 1998: 55).

Urszula Kamińska, when characterizing the phenomenon of social orphanhood, distinguished five basic situations in the child's life that affect social orphanhood. These include the death of one or both parents, the parents' divorce, which makes the children orphans, abandoning children as a result of changing partners or various types of addictions and finally, being overly strict towards the child (Matyjas, 2008: 306).

When completing the definition of social orphanhood, reference should be made to social pedagogy and social work. When characterizing social orphanhood from the perspective of the above-mentioned social sciences, it should be emphasized that it can be a permanent or temporary state. When the orphanhood manifests itself, the child is deprived of opportunities to grow up in their own fam- 
ily. The child's feelings are a key aspect of reflection and interpretation here, which means we should refer to the child's subjective sense of loneliness. The key aspects of social orphanhood include parental attitudes displayed by the child's guardians. The most common ones include the inadequate fulfilment of the parental role and the deliberate renunciation of parental rights. In the latter case, the child care court decides the fate of the child (Lalak, Pilch, 1999: 268).

Another classification of social orphanhood in the literature was formulated by Aleksander Tynelski. He defines social orphanhood as the rejection of the child by the parents and, consequently, the lack of proper care. The author also makes a distinction between various types of social orphanhood due to its causes. $\mathrm{He}$ points to legal, random and emotional orphanhood. Tynelski also considers the situation of breaking the bond between the child and parents, despite the fact of their living together. This perception of social orphanhood is a compatible combination of both the relationship between parents and situations in the child's family. When explaining a specific situation of the child, legal orphanhood should be emphasized, as it is characterized by the interference of a court, which, by virtue of its judgment, limits parental rights or terminates them altogether. The author also indicates the random type of social orphanhood, i.e. resulting from temporary situations, such as parents' illness or imprisonment. The last type of social orphanhood distinguished by Tynelski is the emotional one, which can be characterized as a situation of neglecting the emotional and psychological needs of the child, despite the fact of living together as a family. This type of social orphanhood might also be accompanied by physical violence or other types of child abuse (Tynelski, 1978: 30-33).

\section{Socio-psychological and economic conditions for social orphanhood and their interrelationships}

When addressing the causes of social orphanhood, the child's sense of loneliness should be indicated as the primary cause. At the beginning of the considerations regarding the feeling of loneliness, it is important to realize that this is a state which is difficult to define clearly. Each child has their own individual way of responding to the lack of attention from their parents. However, this condition can be defined as mental loneliness. Its characteristic features include the lack of a bond between the child and parents, non-existent contact with other people, a sense of a lack of attention from loved ones and a lack of sense of belonging to someone. Mirosława Gawęcka defines this condition as a feeling of discomfort for a child who lives 
with their own family, resulting from irregularities in emotional relations between the child and parents. Another important feature of the child's loneliness which Gawęcka points out is the lack of satisfaction of the need for family love and other basic needs of the child (Gawęcka, 2005: 4).

The pedagogical literature emphasizes the importance of psychological conditions that have a significant impact on the emergence of the phenomenon of social orphanhood. When discussing these factors, one should refer primarily to the bio and psychosocial features that manifest themselves in the behaviour of the parents of orphaned children. This set of features of social orphanhood should be understood as the degree of resourcefulness in life, the ability to overcome life crises, the distribution of authority figures in the family and the hierarchy of values (Olearczyk, 2007: 168-169). If difficulties arise in one of these areas, they have a significant impact on the family atmosphere. The results of these difficulties include the parents' inclination to use drugs or alcohol, and to engage in criminal activity. The difficulties described above cause the destruction of family bonds and then of the family itself. The child's parents cannot moderate communication within the family and meet the child's basic needs. If the situation takes the form of a long-term condition, it leads to the parents divorcing, as a result of which the child is forced to remain in the care of one of them. The divorce also entails family reconstruction. Parents who have divorced might make decisions about entering into a new relationship, which can result in their children feeling irrelevant in their lives. That, on the other hand, triggers the child's fear of losing their parents' attention and, ultimately, their love (Olearczyk, 2007: 175-190).

In terms of psychological conditions conducive to the emergence of social orphanhood, various attitudes of parents towards the child are of crucial importance. Alicja Szymborska distinguishes four basic attitudes: rejecting the child, over-correcting the child, avoiding the child and, finally, overprotecting the child. The rejection of the child can be seen as a situation when it becomes a burden to their parents. It is worth emphasizing here that such behaviour on the part of the parents often stems from the fact that they were emotionally unprepared for the role of parents and were not ready to fulfil their parental obligations. Parents believe that the child limits their freedom, because it is impossible for them to act as freely as before the child was born. The features that characterize this attitude include showing negative feelings towards the child as well as criticizing the child and everything they have created or achieved. In such a situation, only the defects and negative qualities of the child are noticed. The main educational methods here are punishments and attempts at intimidating the child. Sometimes, as a result of such a family situation, parents relinquish 
their rights to the child and transfer them to childcare facilities or the child's grandparents (Szymborska, 1969: 106-107).

Another attitude is characterized by over-correcting the child or forcing them to act in the manner strictly designated by the guardians. Parents place such high expectations on their children that they exceed their child's skills and abilities. Finally, parents firmly impose their authority and opinion on the child. All the child's activities are subordinated to the principles set by parents. Any deviation from the rules or spontaneous action of the child is severely punished and criticized. Physical and psychological violence is prevalent in the relationship between the child and parent (Szymborska, 1969: 106-107).

The third attitude conducive to the emergence of the phenomenon of social orphanhood is the attitude of avoidance. The parents do not show any defined feelings towards their child. Their attitude can be described as indifferent. In the emotional sphere, parents demonstrate a complete lack of emotional warmth and indifference towards the child. The time spent together is not a source of satisfaction or happiness. The parents ignore the child's behaviour and do not exercise proper control over the child's health and life (Szymborska, 1969: 106-107).

The last of these attitudes can be described as being overly protective. Parents try to facilitate their child's activity at all costs, sometimes up to the point where they take over altogether. Parents try to protect their child against potential threats at all costs. Such a situation leads parents to a continuous search for threats to their child's life and health. However, growing up in such a family does not leave room for creative and independent actions. Children cannot fully grow up and make independent decisions. Parents characterized by this type of attitude often lead to the isolation of the child and the entire family, which disrupts the child's socialization and development (Szymborska, 1969: 106-110).

In addition to the above-mentioned reasons for social orphanhood, reference should also be made to the material and living conditions of the families of children struggling with social orphanhood. What is important in a situation of that type is the fact that the political and economic situation of the country, in particular the unemployment rate and poverty, have a significant impact on the living conditions of citizens in a given country. Parents cannot perform parental duties properly and meet the child's needs if their financial situation is difficult. Parents need to make decisions on which needs must be satisfied and which will unfortunately be neglected. Such a situation causes frustration in parents, who would like to provide the best developmental conditions for their children. Children, on the other hand, are frustrated because they would like to lead a life similar to their friends and possess the goods their peers do. A difficult financial situation can lead 
to parents engaging in criminal activity, such as thefts. This arrangement of family situations can be conducive not only to the occurrence of social orphanhood, but also to what is broadly understood as the demoralization of children growing up in the family (Kozak, 1986: 50-51).

When discussing the topic of social orphanhood, attention should be paid to the social pressure exerted on young adults, who are about to start their independent lives. Young parents are faced with a necessity of making continuous choices between individuality and family values. Liliana Klimek points out that nowadays, the overall message reaching young people is dominated by the view that they should focus on individual personal development, the need to achieve success in their professional career, and reaching a high social status rather than start a family. Young people most often show a tendency to engage in activities related to developing their interests and realizing their passions. However, they are reluctant to make decisions related to starting a family and having children, as it significantly limits their development opportunities and freedom (Klimek, 2011: 150-153).

In connection with these arguments of both authors, it is important to underline the interrelationships between all factors of family and the impact they have on the formation of social orphanhood. All of these causes interact with each other, causing profound changes in the structure of the family. Responsibility for the family is borne by the child's parents, who often as a result of their own crises or career-related problems, neglect areas of parental activity, which consequently leads to social orphanhood of their children.

\section{Consequences of social orphanhood}

When addressing the consequences of social orphanhood, pseudo orphan syndrome must be also discussed. The literature in the field of psychology and pedagogy defines the pseudo orphan syndrome as a set of serious disorders including the inhibition of both physical and mental development. The medical literature describes pseudo orphan syndrome as a group of somatic disorders that lead to profound changes in the emotional sphere. The disorder develops as a result of depriving the child of sufficient contacts with the mother or a parent figure (Szymborska, 1969: 88-89). An important cause of pseudo orphan syndrome is the spiritual absence of parents and lack of physical contact. This condition is also known as the disease of lack of love. It involves a lack of parental love for the child, but also the child's inability to love their parents. What is more, parents reject their child's love. This condition is chronic and long-lasting, and the first symptoms of 
pseudo orphan syndrome appear in early childhood (Łuczyński, 2011: 99). While it is characteristic for children living in an orphanage, it can also develop among children living in their natural families.

Apart from pseudo orphan syndrome, the negative consequences in the child's development also include a general developmental disorder. Retardation of skeletal development, which leads to growth disorders, is one of its characteristic features. Children experiencing this disorder are unwilling to play games with their peers, which, in turn, might be a major cause of disruption to the socialization process. Delays in cognitive development have also been observed. The children's language acquisition is often disturbed, which may end up in them having limited vocabulary at their disposal. The children do not go through the consecutive developmental stages in a timely manner. In situations like that, children do not develop harmoniously and do not engage in group activities. In relation to all the arguments mentioned, it is safe to state that children suffering from the disorder will grow up to be apathetic, inert and passive in making decisions (Górnicka, 2006: 26-28).

In addition to the reasons outlined above regarding the characteristics of social orphanhood, reference should be made to the emotional states displayed by children living in orphanages. The first one that should be mentioned is the state of deep loneliness. This condition is the result of a lack of satisfaction of the basic needs of love and belonging. The children who have developed the condition in their adolescence are characterized by a lack of sense of security. Their behaviour is often dominated by increasing frustration and anxiety, which eventually turns into aggression. Such children try to release their anger by fighting, quarrels or conflicts, although they might also create defence mechanisms of self-mutilation (Sznajder, 2017: 17).

The second state manifests itself in the attitude of pejorative otherness. The basic mechanism that influences this attitude is the negative memories that the child acquired while being away from home. Children who remain in an orphanage feel different from their peers who have families. The attitude of otherness is accompanied by a sense of harm and loneliness (Sznajder, 2017: 16-17).

The last condition is a sense of existential temporality. The basic stimulus shaping it is a deficit in the sense of security. This is caused by the change of environment from a family home to an orphanage. Children who find themselves in a situation like that are aware that nothing in the facility belongs to them everything is the property of the institution. The behaviour of such children is dominated by impulsivity and more severe experiencing of various emotions (Sznajder, 2017: 17). 
The pedagogical literature provides us with the characteristics of the personality development of children who are affected by social orphanhood. The developmental difficulties such children have to deal with are caused by the fact that their basic needs such as the need for affirmation and belonging to a social group are not fully satisfied. All these factors can lead to the development of Cinderella syndrome. The most common characteristics of Cinderella syndrome include a constant feeling of inferiority, a sense of being inferior and less attractive than others, passivity and helplessness in new and unknown situations. While presenting such a negative self-image, children perceive reality in an extreme way. They believe that one day their fate will change and they will be able to return to their family home. Such people are susceptible to manipulation and easily succumb to authority or those perceived as significant in some way (Łuczyński, 2011: 95-100).

Families of children affected by social orphanhood often display deviant behaviours. While living with such families, children can encounter psychoactive substance abuse, addiction to drugs or alcohol or illegal behaviours. Children exposed to such experiences can base their system of moral values on the behaviours they have observed. Under the influence of the long-term effects of deviant behaviour on a child's moral system, so-called moral blunting can occur. This phenomenon takes the form of desensitizing a child to behaviours which are socially unacceptable. It may lead to drastic consequences, which include criminal activity, drug abuse or engaging in fights with other children in the orphanage (Łuczyński, 2011: 98-100).

\section{Selected activities which compensate for social orphanhood}

Orphanages are the basic form of activity which is meant to compensate for social orphanhood. The main goals of such facilities are to build a replacement environment and create appropriate conditions for physical, mental and social development of children (Raczkowska, 1993: 117). A study conducted by the Central Statistical Office of Poland showed that in 2017 there were 517 orphanages in Poland that looked after 55,716 children (Staniszewska, 2018: 1-3).

Orphanages or children's homes take over tasks that should be performed by parents. One of their basic roles is to perform parental and educational functions. The activities performed by the employees of orphanages are aimed at shaping the independence of children and their ability to live outside the facility. Its basic task is to try to create a substitute for a family home creating a friendly and homely atmosphere. Another crucial area that must be mentioned is the compensating 
activity of meeting emotional needs as well as the sense of belonging and security. The task of all orphanages is to provide children with peace and quiet. The staff aim at eliminating conflicts and fights (Raczkowska, 1993: 43-44). Educators describe one of their basic goals as boosting the students' self-esteem. This is accomplished by underlining the positive aspects of children's activities and skills. The orphanage becomes a support network for children deprived of proper parenting in a home environment. It is a place which provides support and assistance in the event of emergencies (Raczkowska, 1993: 99).

Adoption is a valuable complement to the compensatory measures taken against social orphanhood. It is a lengthy process that begins a year before the planned date for the adoption of the child. In the case of adoption, three states can be indicated, i.e. full, incomplete or complete adoption. The most commonly used form of adoption in Poland is anonymous adoption. All types of adoption are governed by the Family and Guardianship Code. For each of these types of adoption, the child becomes a member of the new family, which in turn becomes a parental environment. By court order, the authority of the biological parents is terminated and is subsequently transferred to adoptive parents. In a situation like that, the child has a chance to grow up in an environment which is conducive to the child's development and to satisfying their emerging needs. An adoptive family not only provides the child with adequate material and living conditions, but also builds a sense of security and belonging to a social group (Wosik-Kawala, 2012: 103-104). Foster parents try to compensate for social orphanhood by creating conditions that ensure family home warmth, stability of life, and mental comfort (Zawada, 2010: 102-104).

All the forms and methods of social orphanhood compensation mentioned above can be described as state-ensured forms. However, it is important to refer to forms of non-governmental assistance. SOS Kinderdorf International is an organization of that type. The Polish branch of the organization is Stowarzyszenie SOS Wioski Dziecięce (SOS Children's Villages Association). The main function of the organization is to help children deprived of care by their parents or immediate family. When describing the structure of each individual family village, the function of SOS Mothers should be described, as it is crucial for the organization. Each mother has an assigned home that she runs and where she brings up her assigned children. The mother and her assigned children form a family, which is called a community. Each family has their own home, where they live together with assisting psychologists or pedagogues (Łobocki, 2011: 30).

The main idea of the villages is to provide long-term childcare. Raising children there follows four basic principles. The first one is the SOS Mother, who accepts 
responsibility for raising her children, creating a relationship based on friendship and close attachment. The next principle is the community. It assumes that everyone in the village coexists on friendly terms. Everyone is ready to help each other. Home is the third principle. Home is the most significant place, because it plays a significant role in upbringing. It is the place where every child has the opportunity to solve problems among their close ones. Siblings constitute the last principle. The child who comes to the village with their siblings gets a guarantee that they will live together in the same house (Łobocki, 2011: 36-37).

SOS Wioski Dziecięce (SOS Children's Villages) and families emerging within the structure allow children to spend their childhood in an atmosphere of respect, love and peace. The primary goal of the organization is to raise children and help them develop in the physical, mental as well as moral and social area. All relationships are based on mutual respect and acceptance. Each child has the right to be an individual and express their own views (Łobocki, 2011: 89-90).

\section{A brief afterthought:}

Social orphanhood is a complex and multi-faceted phenomenon. The knowledge about it must be expanded, especially in the field of assistance and effective support and prevention. There is no doubt that we still face the need to create new solutions and reform the system that currently exists in Poland. This article enumerates only some of the issues regarding the phenomenon of social orphanhood; the ones which have been presented here do not exhaust the full spectrum of issues related to social orphanhood in Poland. It is rather a starting point for an in-depth analysis, not only in the theoretical but also in the empirical and practical dimensions. Finally, I think it is worth noting that the literature on childcare promotes supporting children and families in the local environment, increasing the responsibility of families and the local communities for the child, the active attitude of parents in determining methods and forms of overcoming any difficult situations, and most of all, referring to the strengths of the family environment.

\section{Bibliography}

Czeredrecka B. (1988), Potrzeby psychiczne sierot społecznych, Warszawa.

Gawęcka M. (2005), Poczucie osamotnienia dziecka w rodzinie własnej, Toruń.

Górnicka B. (2006), Zaniedbywanie dziecka -wybrane aspekty zjawiska, Opole. 
Klimek L. (2011), Dysfunkcjonalność rodziny jako główne źródło sieroctwa społecznego we współczesnej Polsce, [in:] S. Bębas (ed.), Zagrożenia i problemy wspótczesnej rodziny, Radom.

Kozak S. (1986), Sieroctwo społeczne, Warszawa.

Lalak D., Pilch T. (1999), Elementarne pojęcia pedagogiki społecznej i pracy socjalnej, Warszawa.

Łobocki M. (2011), O SOS Wioskach Dziecięcych, Kraków.

Łuczyński A. (2011), Dzieci w rodzinach zastępczych i dysfunkcjonalnych, Lublin.

Matyjas B. (2008), Dzieciństwo w kryzysie, Warszawa.

Olearczyk T. (2007), Sieroctwo i osamotnienie. Pedagogiczne problemy kryzysu wspótczesnej rodziny, Kraków.

Raczkowska J. (1973), Wychowanie w domu dziecka, Warszawa.

Raczkowska J. (1993), Dom dziecka, [in:] W. Pomykało, (ed.), Encyklopedia pedagogiczna, Warszawa.

Sołtysiak T. (1998), Sieroctwo społeczne, Włocławek.

Staniszewska J. (2018), Raport o pieczy zastępczej, Urząd Statystyczny w Krakowie, Ośrodek Statystyki Pomocy Społecznej, Kraków.

Sznajder D. (2017), Rola osoby znaczacej w kształtowaniu obrazu siebie sieroty społecznej, Kraków.

Szymborska A. (1969), Sieroctwo społeczne, Warszawa.

Tynelski A. (1978), Problemy sieroctwa naturalnego i społecznego, Biuletyn TWWP, nr 2.

Wosik-Kawala D. (2012), Rodzinne i instytucjonalne środowiska opiekuńczo-wychowawcze, Lublin.

Zawada A. (2010), Wybrane zagadnienia pomocy społecznej i opieki w Polsce w okresie ponowoczesności, Kraków.

Ziemska M. (1973), Postawy rodzicielskie, Warszawa. 